\title{
Reflection on Basic View of Public Infrastructure for Infrastructure Asset Management in Indonesia
}

\author{
Pemikiran tentang Pandangan Dasar Infrastruktur Publik bagi \\ Manajemen Aset Infrastruktur di Indonesia
}

\author{
Hitapriya Suprayitno $^{1, \mathrm{a})}$ \& Ria Asih Aryani Soemitro ${ }^{1, \mathrm{~b})}$ \\ ${ }^{1)}$ Civil Engineering Department, Institut Teknologi Sepuluh Nopember (ITS), Surabaya.
}

Corespondance : ${ }^{\text {a) }}$ suprayitno.hita@gmail.com \& b)ria@ce.its.ac.id.

\begin{abstract}
ABSTRAK
Infrastructure Asset Management is essential. In Indonesia nowadays, they, who enter and take a role in Infrastructure Asset Management is either an engineer or an economist. Both the engineer and the economist tend to see the infrastructure in infrastructure engineering way and the economy of infrastructure. A Basic View of Public Infrastructure for Infrastructure Asset Management in Indonesia needs to be formulated. The Public Infrastructure is viewed through several different following basic concepts: Infrastructure System, Infrastructure Function, Infrastructure SupplyDemand, Infrastructure Capacity, Infrastructure Operation, Infrastructure Deterioration, Infrastructure Maintenance, Infrastructure Life Cycle, Infrastructure Economics, Infrastructure Performance, Infrastructure Taxonomy.
\end{abstract}

Kata Kunci : infrastructure asset management, basic view of public infrastructure.

\section{INTRODUCTION}

In Indonesia, during the last ten years, the Public Treasury Asset Management is becoming essential. An Indonesian Code on State Treasury was established in 2014, well known as Indonesian Law Number 1 the Year 2004 about State Treasury (UU 1/04). This Code was soon followed by its derivative, the Government Regulation on State-Owned Asset Management. This Government Regulation established twice, well known as Government Regulation Number 6 the Year 2006 and followed by its betterment version the Government Regulation Number 27 the Year 2014. These Code and Regulations stipulated that the Ministry of Finance function as the leading sector. The Asset Management of State and Regional Public Infrastructure covered by this Code and Government Regulation (UU 1/04; PP 6/06; PP 27/14).

In Indonesia, most Public Infrastructures are under the Public Works and Transportation sectors. In the three Governmental Sectors: Finance, Public Works and Transport, the Infrastructure Asset Management (IAM) domain is generally entered by Engineers and Economists. They usually know well about Infrastructure Engineering and Economic Development, Management, and Accounting. Meanwhile, Infrastructure Management knowledge is different from Infrastructure Engineering the Engineer know well, and also very different from Economic Development, Management and Accounting normally the Economist know well (Soemitro \& Suprayitno 2018; Suprayitno \& Soemitro 2018). So a Basic View of Public Infrastructure for Infrastructure Asset Management needs to be formulated.

This paper present an attempt to formulate the Basic View of Public Infrastructure for Infrastructure Asset Management in Indonesia. 


\section{RESEARCH METHOD}

This research was conducted by following these steps: background statement, research objective statement, research method, literature review, concept development, and finalized by conclusions.

Concept Development is started by understanding the context in which the formulated object is located. Based on this context, the basic view of infrastructure is formulated. The formulation is continued by particular derivative formulation needed, and mainly related notion needs to be expressed.

\section{LITERATURE REVIEW}

Infrastructure Asset Management (IAM) is defined as slightly lexically in a different way across several various references. In the case of Indonesian Public Infrastructure, three different definition expressions will be taken as references. Those are from an Indonesian IAM Journal : Jurnal Manajemen Aset Infrastruktur \& Fasilitas (JMAIF), from an Indonesian Code : Government of Indonesia Regulation Numero 27 Tahun 2014 about State/Region Owned Asset Management (PP 27/14), and from an International Standard: ISO 55000 Asset management: overview, principles, and terminology (ISO 5500). The three are presented below.

\section{Indonesian IAM Journal : JMAIF}

In JMAIF, Infrastructure Asset Management is defined as a program and knowledge to manage the infrastructure through its life cycle to be able to function sustainably well, economically, efficiently, effectively and in conformity with sustainable principle (green principle : social, economic, environmental) (Soemitro \& Suprayitno 2018; Suprayitno \& Soemitro 2018).

2. Indonesian Government Regulation: PP 27/14

Government Regulation Number 27 the Year 2014, Article 3 stipulates that The management of State and Regional Owned Treasury (SaROT) is executed based on functionality principal, legal certainty, transparency, efficiency, accountability, and value certainty. The management of the SaROT consists of necessity and procurement budgeting planning, acquisition, utilization, safekeeping and maintenance, valuation, hand-over, liquidation, disposal, administration, and coaching surveillance and control (PP 27/14). Public Infrastructure is part of SaROT.

\section{International Standard: ISO 55000 series}

The ISO 55000 series look at Asset Management from the Asset Managing Organization. The Asset Management need to consider: the nature and purpose of the organization, its operating context, its financial constraints, and regulatory requirements, and the needs and expectation of organization and stakeholder. Asset Management translates the organization's objective into asset-related decisions, plans, and activities, using a risk-based approach (ISO 55000; ISO 55001; ISO 55002).

Other IAM definition can be found in several papers which can be downloaded easily through Google (Halfway et al. 2005; Lee et al. 2010; Wikipedia 2018).

\section{CONCEPT DEVELOPMENT ON BASIC VIEW OF INFRASTRUCTURE}

\section{IAM Principle}

Infrastructure Asset Management (IAM) is a program and knowledge to manage the infrastructure through its life cycle to be able to function sustainably well, economically, efficiently, effectively and in conformity with sustainable principle (green principle: social, economic, environmental) (Soemitro \& Suprayitno 2018; Suprayitno \& Soemitro 2018). 
Regarding the above IAM definition, a notion to be further developed and formulated are IAM System, Basic View of Infrastructure, Infrastructure Function, Infrastructure SupplyDemand, Infrastructure Operation, Infrastructure Deterioration, Infrastructure Maintenance, Infrastructure Life Cycle, Infrastructure Certification \& Administration, Infrastructure Economics, and Infrastructure Taxonomy.

It must also be noted that infrastructure management is not infrastructure engineering. These two concepts are inter-related each other, but different between the one to the other. Even though Infrastructure Management needs knowledge of Infrastructure Engineering to some extent, therefore the way, the Infrastructure Asset Manager sees the infrastructure is slightly different from the Engineer see the same object.

The Basic View of the Public Infrastructure can be seen more clearly through the understanding of IAM System. The IAM System is formulated below.

\section{IAM System}

IAM System is the System to Manage an Infrastructure. The IAM System consists of a set of Management Manual, Standard Operating Procedure, Management Activity Program, Organization, and Man Power, which are deliberately developed to manage an infrastructure to be able to function sustainably well, economically, efficiently and effectively and in conformity with the green sustainable principle.

Based on Infrastructure System Data Base, the IAM System consists of three fundamental actions: infrastructure evaluation, developing the strategic program plan, and developing and executing the annual program. This principle is presented in Figure 1 below.

Afterward, the notion of being defined is the Basic View of Infrastructure System for Infrastructure Asset Management. It can be noted that the Basic View must be developed on Infrastructure System thing.

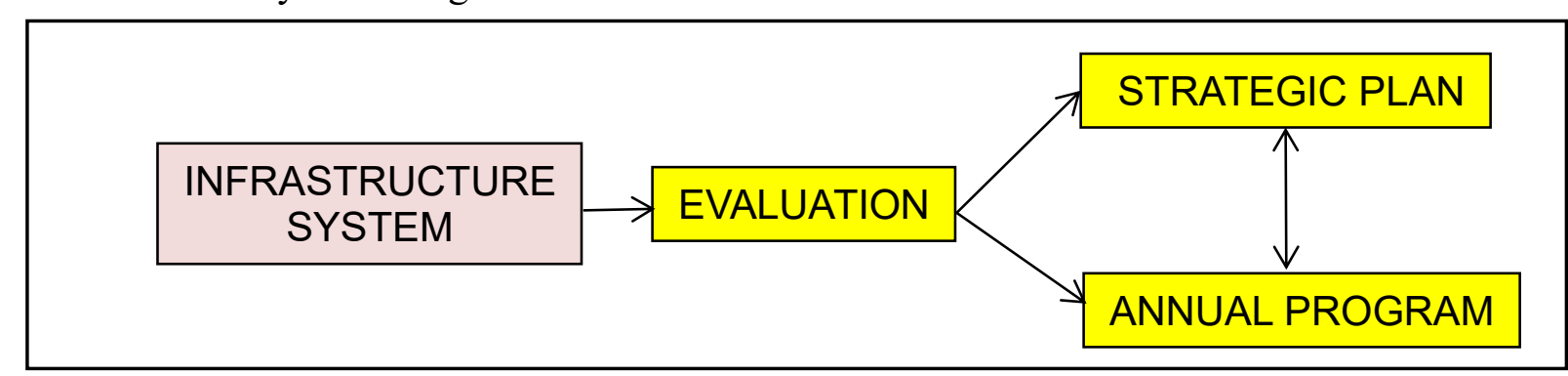

Figure 1. Diagram of IAM System

\section{Basic View of Infrastructure System for IAM}

Basic View of Infrastructure System must be based on the fact that infrastructure is constructed because a particular region needs the infrastructure. So the infrastructure is built to serve the served area. In the served region, there are users of the infrastructure. Infrastructure is an integral part of a region. The infrastructure system consists of the infrastructure, the served region, and the users. The users can be of various forms. Diagram of the Infrastructure System is presented in Figure 2 below.

In serving the Served Region, the Infrastructure must be functional. Infrastructure has a particular function to be well executed for serving the Served Region. Thus, a concept of Infrastructure Function needs to be formulated. 


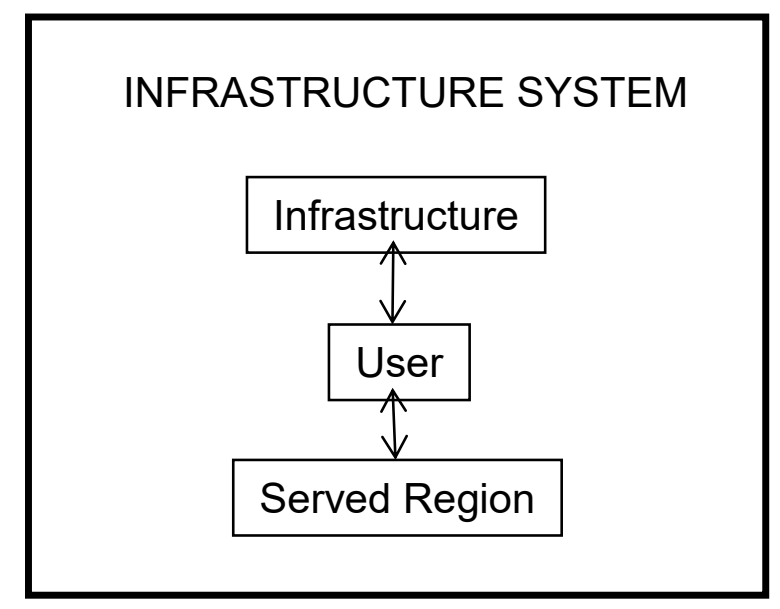

Figure 2. Diagram of Infrastructure System

\section{Infrastructure Function}

An infrastructure is an object who delivered a function to the area or region to which the role is designated. Infrastructure function is what for the infrastructure is built. This notion is a fundamental part of the IAM and the Basic View of Infrastructure. The function can consist of the primary function and the secondary function. The function has the attribute of a function. A function has loading and capacity. The attribute has an ideal level, either maximum or minimum. The function is performed based on physical condition and hierarchy.

Related to the Function, the Infrastructure Basic View can be presented diagrammatically in Figure 3 below.

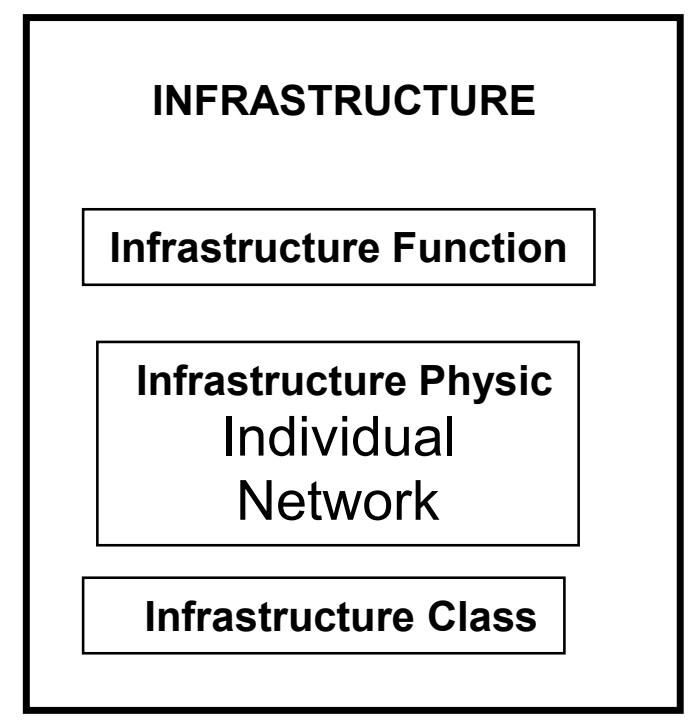

Figure 3. Infrastructure Diagram

As an example, Road Infrastructure, its primary function is to flow traffic. This function must be executed with a particular quality attribute: safely, safety, comfort. The Road Function definition is presented in Table 1 below. 
Table 1. Example of Infrastructure Function - Road

\begin{tabular}{lll}
\hline Road Ne twork Function & Explanation \\
\cline { 2 - 3 } to connect nodes & accessibility & $\begin{array}{l}\text { wether all nodes which should be } \\
\text { connected are connected. }\end{array}$ \\
\cline { 2 - 3 } to flow traffic & itinerary & $\begin{array}{l}\text { distance of a node from the others or of } \\
\text { all nodes from a node, measured in km or } \\
\text { hour. }\end{array}$ \\
\cline { 2 - 3 } & fluidity & $\begin{array}{l}\text { wether the existing itinerary from node A } \\
\text { to node B is not too far caused by turn } \\
\text { around. }\end{array}$ \\
\hline to cover the region & coverage & $\begin{array}{l}\text { wether the traffic flow in rad segment } \\
\text { and intersection is enough fluid or not. }\end{array}$ \\
\cline { 2 - 3 } to support economic & number of bussines & $\begin{array}{l}\text { numbe of population covered or served } \\
\text { region's area covered. }\end{array}$ \\
\hline to make green area & number of tree & $\begin{array}{l}\text { the road density against the population } \\
\text { number or served area. }\end{array}$ \\
\hline
\end{tabular}

\section{Infrastructure Supply-Demand}

In executing its function, the Infrastructure undergoes a demand for utilization generated by its served area. The demand for usage must be able to be supported by the infrastructure capacity. The demand exists in a different form for different infrastructure. An infrastructure can experience more than a single form of demand for utilization.

Demand is generated directly by the Served Region Characteristics: mainly the land use, the population, and the economic level. Demand itself has its specific behavior across a different hour of the day, different day of the week, different season, a diverse group of users, and others. This principle is illustrated in Figure 4 below.

\begin{tabular}{|c|c|}
\hline \multirow{2}{*}{ Supply } & Infrastructure \\
\cline { 2 - 2 } & Operation System \\
\cline { 2 - 2 } Loading Factor & Infrastructure Capacity \\
\hline \multirow{3}{*}{ Demand } & Demand/Capacity \\
\cline { 2 - 2 } & Land Use, Population, Economic Condition \\
\cline { 2 - 2 } & Served Region \\
\hline
\end{tabular}

Figure 4. Diagram of Infrastructure Supply-Demand 
Urban Electric Power Distribution Facilities endure a Demand for Electricity. This demand is generated by different land-use of the city. The residential area electrical demand rise during the night, while the office area the demand of electricity rise during working hour, while the industrial area generates peak hour demand during the working hour but with an intensity far beyond the office area and need a very high voltage. Example of different forms of Infrastructure Demand and Supply is presented in Table 2 below.

Table 2. Example of Infrastructure Demand and Supply

\begin{tabular}{lll}
\hline Infras tructure & De mand & Supply \\
\hline road segment & traffic volume & road capacity \\
primary school & age children in served zone & total class cpacity \\
hospital type D & number of population in kabupaten & number of beds \\
\hline
\end{tabular}

\section{Infrastructure Operation}

To be operated is the ultimate reason why the infrastructure is constructed. The infrastructure operation can be very simple or very complex. The infrastructure function performance depends on its operational quality, while this operational quality depends on its physical condition, thus its maintenance quality. Examples of Infrastructure operation is presented in Table 3 below.

Table 3. Example of Infrastructure Operation

\begin{tabular}{ll}
\hline Infrastructure & Ope ration Syste m \\
\hline Road Network & traffic management \\
Railway Network & train travel graph \\
IPA & production, transmission, distribution of potable water \\
School & opening hour, classroom utilisation agenda \\
\hline
\end{tabular}

\section{Infrastructure Deterioration and Maintenance}

Each infrastructure experience deterioration. Always being able to function well, the infrastructure must always be in good condition. Thus, Infrastructure Maintenance is something which has to be conducted well. Examples of Infrastructure Deteriorations are presented in Table 4 below.

Table 4. Example of Infrastructure Deterioration

\begin{tabular}{ll}
\hline Infras tructure & Deterioriation Form \\
\hline irrigation channel & landslide \\
irrigation box & water gate can not be moved \\
electrical grid & trouble in step-down post \\
bridge & collapse \\
school & collapse \\
road & alligator cracks \\
\hline
\end{tabular}

\section{Infrastructure Life Cycle}

The Infrastructure Life Cycle is started from the Idea of Infrastructure Need, followed by Infrastructure Planning, Infrastructure Design, Infrastructure Construction. After the Infrastructure has been constructed, the Infrastructure then can be utilized, means operated and maintained. But, beforehand, the infrastructure needs to be certified and administrated. 
During utilization, each time the infrastructure need to be evaluated for developing annual infrastructure program. At a certain condition, the infrastructure can be disposed, if the infrastructure is no longer needed to serve the Served Region.

The whole Infrastructure Life Cycle can be presented as a Diagram of Infrastructure Life Cycle in Figure 5 below.

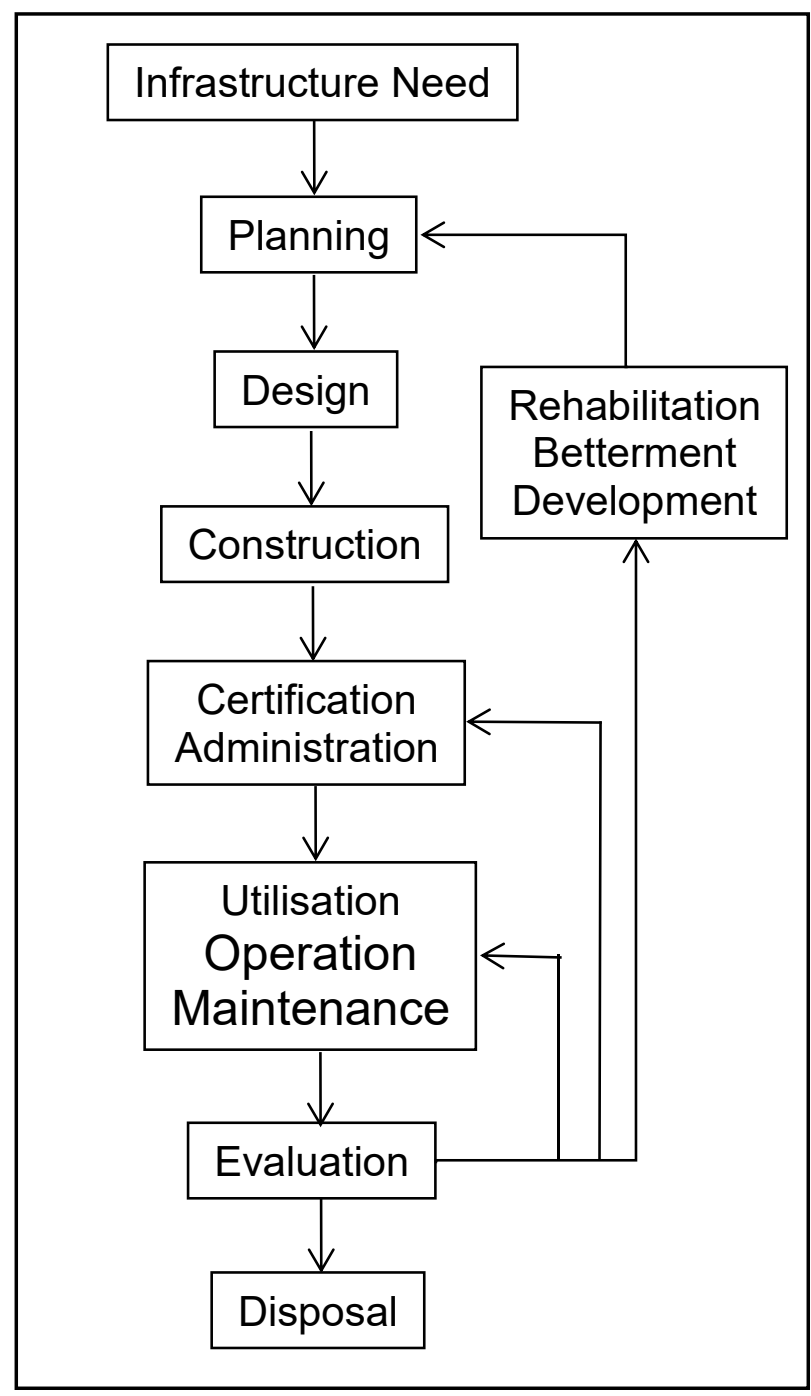

Figure 5. Diagram of Infrastructure Life Cycle

\section{Infrastructure Certification \& Administration}

Infrastructure must be certified and administrated. The Certification, principally, consists of technical and administrative certification. The technical certification is to confirm whether the infrastructure is in good condition to be operated. The administrative certification consists of land certification and other administrative certification. The Infrastructure Administration, among others, consists of infrastructure registration, usage definition, etc.

\section{Infrastructure Economics}

Infrastructure Economics knowledge is divided into three level, i.e., micro view, meso view, and macro perspective. The micro view observes the economics of a single infrastructure. It is about, for example, the economic and financial feasibility, optimizing the maintenance. The meso view sees the economics of infrastructure management based on different management organization. While the macro view observes the regions budget 
capacity for infrastructure versus the need for infrastructure, the role of infrastructure for regional economics.

\section{Infrastructure Taxonomy}

Some infrastructures have similar characteristics in terms of function, operation system, economic aspects. Apart from this, infrastructure can also be classified into different sectors. Thus Infrastructure Taxonomy needs to be developed, based on the infrastructure sector, infrastructure function typology, infrastructure structure, infrastructure operation system, etc.

\section{CONCLUSIONS}

The concept development of the Basic View of Public Infrastructure for Infrastructure Asset Management has been successfully finished. In principle the Basic View consists of several following Basic Concepts :

- Infrastructure Taxonomy

- Infrastructure Asset Management System

- Infrastructure System

- Infrastructure Function

- Infrastructure Supply-Demand

- Infrastructure Operation System

- Infrastructure Deterioration and Maintenance

- Infrastructure Life Cycle

- Infrastructure Certification and Administration

- Infrastructure Economics

- Infrastructure Taxonomy

Further curiosities still need to be answered. Those are developing a preliminary concept of infrastructure asset management system, developing a basic view of infrastructure in term of function, develop infrastructure taxonomy, infrastructure function typology, infrastructure economics, etc.

Notes. This paper is a part of working documents for developing the Theory of Infrastructure Asset Management.

\section{REFERENCES}

Halfway, M., Newton, L. \& Vanier, D. (2005). Municipal Infrastructure Asset Management System: State-of-the-Art Review. National Research Council of Canada. Ottawa.

ISO 55000. International Standard ISO 5500. Asset Management - Overview, Principles, and Terminology. First Edition 2014-01-15. International Standard Organization.

ISO 55001. International Standard ISO 55001. Asset Management - Management System Requirements. International Standard Organization.

ISO 55002. International Standard ISO 55002. Asset Management - Management SystemGuideline for Application of ISO 55001. International Stndard Organization.

Lee, S-H., Park, S. \& Kim, J.M. (2010). "Suggestion for A framework for a Sustainable Infrastructure Asset Management Manual in Korea". Sustainability 2015 (7) 1500315028, doi : 10.3390/su71115003.

PP 6/06. Peraturan Pemerintah Republik Indonesia Nomor 6 Tahun 2006 tentang Pengelolaan Barang Milik Negara/Daerah

PP 27/14. Peraturan Pemerintah Republik Indonesia Nomor 27 Tahun 2014 tentang Pengelolaan Barang Milik Negara/Daerah. 
Soemitro, R.A.A. \& Suprayitno, H. (2018). "Pemikiran Awal tentang Konsep Dasar Manajemen Aset Fasilitas". Jurnal Manajemen Aset Infrastruktur \& Fasilitas, Volume 2, Suplemen 1, Juni 2018, Hal. : 1-14.

Suprayitno, Hitapriya (2014). "Metoda Penilaian Kualitas Jaringan Jalan Utama di Wilayah Kabupaten”. Disertasi RC 09-3399. Jurusan Teknik Sipil, Institut Teknologi Sepuluh Nopember (ITS). Surabaya.

Suprayitno, Hitapriya (2015). “Traffic Flow Quality as Part of Network Quality for a Sparse Road Network". Proceedia Engineering 125 (2015) 564-570.

Suprayitno, H. \& Soemitro, R.A.A. (2018). "Preliminary Reflexion on Basic Principle of Infrastructure Asset Management”. Jurnal Manajemen Aset Infrastruktur \& Fasilitas, Volume 2, Nomer 1, Maret 2018, Hal. : 1-10.

UU 1/04. Undang Undang Republik Indonesia Nomor 1 Tahun 2004 tentang Perbendaharaan Negara.

Wikipedia (2018). "Infrastructure Asset Management".

http://en.wkipedia.org/wiki/Infrastructure_asset_management. 


\section{(e)ISSN 2615-1847 (p)ISSN 2615-1839}

Jurnal Manajemen Aset Infrastruktur \& Fasilitas - Vol. 3, Sup. 1, Juni 2019 